\title{
FEATURES OF APPLICATION OF THE METHANE-HYDROGEN FRACTION AS FUEL FOR THERMAL POWER PLANT BOILERS
}

\author{
M.A. Taymarov, V.K. Ilyin, E.G. Chiklyaev, R.G. Sungatullin \\ Kazan State Power Engineering University
}

\begin{abstract}
The methane-hydrogen fraction is a gaseous hydrocarbon by-product during oil processing for obtaining petroleum products. Until recently, the methane-hydrogen fraction was used as furnace oil in internal technological processes at a refinery. Some of the low-calorie methane-hydrogen fraction was burned in flares. Driven by the prospect of the methane-hydrogen fraction use as a fuel alternative to natural gas for burning in thermal power plants boilers, it became necessary to study the methane-hydrogen fraction combustion processes in large volumes. The conversion of ON-1000/1 and ON-1000/2 furnaces from the combustion of the methanehydrogen fraction with combustion heat of $25.45 \mathrm{MJ} / \mathrm{m}^{3}$ to the combustion of the composition with combustion heat of $18.8 \mathrm{MJ} / \mathrm{m}^{3}$ leads to a decrease in temperature in the flame core for $100{ }^{\circ} \mathrm{C}$ as an average. The intensity of flame radiation on the radiant tubes decreases. Therefore, the operation of furnaces during combustion of methane-hydrogen fraction with a low heat of combustion at the gas oil hydro-treating unit is carried out only with a fresh catalyst, which allows lower flame temperatures in the burner.

The experiments to determine the concentration of nitrogen oxides NOx and the burning rate $w$ of the methane-hydrogen fraction in the ON-1000/1 furnace and natural gas in the TGM-84A boiler, depending upon the heat of combustion $Q_{n}{ }^{r}$ were carried out. The obtained results showed that the increase in the hydrogen content $\mathrm{H}_{2}$ from $10.05 \%$ to $18.36 \%$ (by mass) results in an increase in the burning rate $w$ by $45 \%$. The burning rate of natural gas with methane $\mathrm{CH}_{4}$ content of $98.89 \%$ in the TGM-84A boiler is $0.84 \mathrm{~m} / \mathrm{s}$, i.e. it is 2.5 times lower than the burning rate of the methanehydrogen fraction with $\mathrm{H}_{2}$ content of $10.05 \%$. The distributions of heat flux from the flame $q_{f}$ over the burner height $h$ in the TGM-84A boiler were obtained in case of natural gas burning and calculation of burning of the methane-hydrogen fraction with a hydrogen content of $10.05 \%$ and methane of $28.27 \%$. The comparison of the obtained data shows that burning of methanehydrogen fraction causes an increase in the incident heat flux $q_{f}$ at the outlet of the burner.
\end{abstract}

Keywords: thermal power plants; methane-hydrogen fraction; burning; combustion; heating oil; vacuum gas oil; power boilers; burning rate; temperature; natural gas; heat; flame; burners; boiler.

For citation: Taymarov MA, Ilyin VK, Chiklyaev EG, Sungatullin RG. Features of application of the methane-hydrogen fraction as fuel for thermal power plant boiler. Power engineering: research, equipment, technology. 2019; 21(3):109-116. (In Russ). doi:10.30724/1998-9903-201921-3-109-116.

\section{ОСОБЕННОСТИ ПРИМЕНЕНИЯ МЕТАНО-ВОДОРОДНОЙ ФРАКЦИИ В КАЧЕСТВЕ ТОПЛИВА ДЛЯ КОТЛОВТЭС}

\author{
М.А. Таймаров, В.К. Ильин, Е.Г. Чикляев, Р.Г. Сунгатуллин
}

Казанский Государственный Энергетический Университет, г. Казань, Россия. 
Резюме: Метано-водородная фракиия является побочным газообразным углеводородным продуктом при переработке нефти с получением конечных нефтепродуктов. До последнего времени метано-водородной фракция использовалась как печное топливо на НПЗ во внутренних технологических процессах. Некоторая часть низкокалорийной метано-водородной фракции сжигалась в факелах. В связи с перспективной использования метано-водородной фракции как топлива альтернативного природному газу для сжигания в энергетических котлах тепловых электростанций возникла необходимость изучения процессов горения метано-водородной фракции в больиих объемах. Перевод печей ОН1000/1 и ОН-1000/2 с сжигания метано-водородной фракции с теплотой сгорания

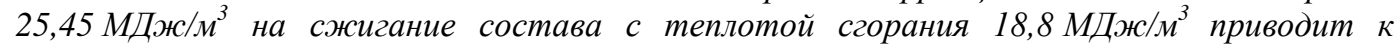
снижению температуры в ядре факела в среднем на $100{ }^{\circ} \mathrm{C}$. Интенсивность излучения факела на радиантные трубы уменьшается. Поэтому эксплуатация печей при сжигании метано-водородной фракциии с низкой теплотой сгорания на установке гидроочистки газойля проводится только при свежем катализаторе, допускающем более низкие температуры факела в топке.

Полученные авторами результаты экспериментов по определению концентрации оксидов азота $\mathrm{NO}_{x}$ и скорости горения $w$ метано-водородной фракции в печи ОН-1000/1 $u$ природного газа в котле ТГМ-84А в зависимости от теплоть сгорания $Q_{H}{ }^{2}$ показали, что увеличение содержания водорода $\mathrm{H}_{2}$ с 10,05\% (по массе) до 18,36\% приводит к росту скорости горения $w$ на $45 \%$. Скорость горения природного газа с содержанием метана $\mathrm{CH}_{4}$ 98,89\% в котле ТГМ-84A составляет 0,84 $\mathrm{M} / \mathrm{c}$, то есть в 2,5 раза ниже скорости горения метано-водородной фракиии с содержанием $\mathrm{H}_{2}$ 10,05\%. Распределение тепловых потоков от факела $q_{\phi}$ по высоте топки в сравнении с расчетными данньли при сжигании метано-водородной фракции при содержании водорода 10,05\% и метана 28,27\% показывает, что сжигание метановодородной фракции вызывает рост падающих тепловых потоков $q_{\phi}$ на выходе из топки.

Ключевые слова: тепловые электрические станции; метано-водородная фракция; сжигание; горение; печное топливо; вакуумный газойль; энергетические котль; скорость горения; температура; природный газ; теплота; факел; горелки; котел

\section{Introduction}

The methane-hydrogen fraction is formed at the refinery during the process of deep oil processing. It is a by-product that, at its large production volumes is used as fuel for technological furnaces, depending on the composition and its calorific value, and at small production volumes it is burned in flames [1-5]. Nowadays, it is planned to use the methane-hydrogen fraction as a gaseous alternative fuel for power boilers of thermal power plants $(T P P)$. However, there are some features of the chemical composition and combustion process of the methane-hydrogen fraction associated with the hydrogen content. This circumstance does not allow utilizing the methanehydrogen fraction as a substitute for natural gas without a detailed study of its heat and energy characteristics during combustion. Therefore, the study on this topic is relevant.

\section{Object description}

The properties of the methane-hydrogen fraction were experimentally studied using the operating furnace equipment $O N-1000 / 1$ and $O N-1000 / 2$ of the vacuum gas oil hydrotreatment unit of workshop No. 2 at JSC Ryazan Oil Refining Company. TGM-84A boilers were considered as research objects where it is planned to use the methane-hydrogen fraction as fuel instead of natural gas. During the experiments, the TERA-50 total radiation radiometers were used to measure the heat fluxes, and dual chromel-alumel thermocouples [6] and the ThermaCAMP-50F thermographic camera were used to determine the flame temperature. The composition of the samples of the methane-hydrogen fraction was analyzed in the central factory laboratory. The experimental procedure for measuring the operation parameters of furnaces and the boiler is described in [7]. The operation parameters of the $T G M-84 B$ boilers during combustion of the 
methane-hydrogen fraction were calculated using [8-12]. The scheme of the $O N-1000 / 1$ and $O N-$ $1000 / 2$ furnaces, which were used to study the regime parameters of the combustion process of the methane-hydrogen fraction, is shown in Fig. 1.

The dimensions of the burners of the $O N-1000 / 1$ and $O N-1000 / 2$ furnaces are: length is 8.6 $\mathrm{m}$, width is $3.3 \mathrm{~m}$, height is $5.5 \mathrm{~m}$. $L E-C F S G-2 W$ bottom gas burners 1 in the amount of 40 pcs. are made as single pipes with an outlet diameter of gas supply openings of $6.3 \mathrm{~mm}$ and provide a flow rate of methane-hydrogen fraction per furnace in the amount from 1000 to $1500 \mathrm{~m}^{3} / \mathrm{h}$.

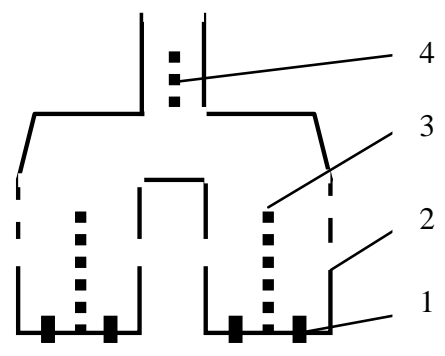

Fig. 1. Cross section of the ON-1000/1 and ON-1000/2 furnaces:

1 - burners; 2 - hatches; 3 - radiate coil; 4 - convective coil

\section{Research methodolo}

The heat fluxes and temperatures incident from the flame were measured through the side hatches 2 . The heat of combustion of the methane-hydrogen fraction is received in the burner by radiating coils 3 (see Fig. 1), which provide heating of vacuum gas oil in the amount of $177 \mathrm{t} / \mathrm{h}$ in a mixture with hydrogen-containing gas in the amount of 97.4 thousand $\mathrm{m}^{3} / \mathrm{h}$ and convective coils 4 in the chimney.

The product is heated from $322{ }^{\circ} \mathrm{C}$ to $347^{\circ} \mathrm{C}$. The temperature of the outer surface of the radiant coils as measured by ThermaCAMP-50F thermographic camera is $530{ }^{\circ} \mathrm{C}$.

The scheme of the $T G M-84 A$ boiler, for which the possibility of using the methane-hydrogen fraction as a fuel instead of natural gas is considered, is shown in Fig. 2.
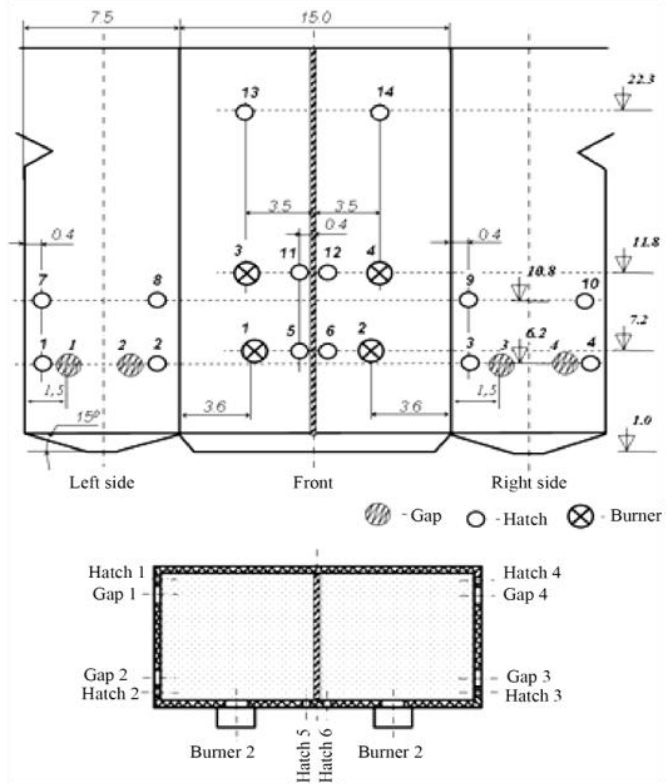

Fig. 2. The scheme of the $T G M-84 A$ boiler 
The $T G M-84 A$ boiler is a gas-oil drum boiler, which is characterized by steam capacity of $420 \mathrm{t} / \mathrm{h}$, steam parameters of $560{ }^{\circ} \mathrm{C}$ and pressure of $14 \mathrm{MPa}$. The furnace is divided in height into two halves by a partition wall. The burner has the following dimensions: width is $15 \mathrm{~m}$, depth is $7.5 \mathrm{~m}$, height is $27 \mathrm{~m}$. Burners of 2 pcs. are located at heights of 7.2 and 11.8 $\mathrm{m}$. The natural gas consumption for the TGM-84A boiler at a nominal capacity of $420 \mathrm{t} / \mathrm{h}$ is 32.5 thousand $\mathrm{m}^{3} / \mathrm{h}$ for the lower calorific value $Q_{\mathrm{n}}{ }^{\mathrm{r}}=34.24 \mathrm{MJ} / \mathrm{m}^{3}$ and the following gas composition: methane $\mathrm{CH}_{4}=98.89 \%$ (by mass), ethane $\mathrm{C}_{2} \mathrm{H}_{6}=0.47 \%$, propane $\mathrm{C}_{3} \mathrm{H}_{8}=0.18 \%$, nitrogen $\mathrm{N}_{2}=0.76 \%$. The HF-TsBK-VTI-TKZ vortex burners are installed at the TGM- $84 \mathrm{~A}$ boiler, with a unit power of $76.7 \mathrm{MW}$ when operating on gas, with peripheral tubular gas distribution: 12 pcs. of the $\varnothing 23$, and 12 pcs. of the $\varnothing 33$. The air swirl is dual-flow in hot air and consists of two sections of the axial (central) swirl and one section of the tangential (peripheral) swirl.

\section{Research results}

The compositions of the methane-hydrogen fraction used as fuel for the $O N-1000 / 1, O N$ 1000/2 furnaces for heating vacuum gas oil at JSC Ryazan Oil Refining Company are given in Table. 1.

Table 1

Compositions of samples of methane-hydrogen fraction used as fuel for furnaces ON-1000/1 and ON-1000/2 for heating of vacuum gas oil at a hydrotreating unit

\begin{tabular}{|c|c|c|c|c|c|c|c|c|c|c|}
\hline $\begin{array}{c}\text { Sample } \\
\text { No. }\end{array}$ & $\begin{array}{c}\text { Density } \\
\rho \text { at } \\
760 \mathrm{~mm} \\
\mathrm{Hg} \text { and } \\
0^{\circ} \mathrm{C}, Q_{\mathrm{n}}{ }^{r}\end{array}$ & $\begin{array}{c}\text { Hydroge } \\
\text { n, \% by } \\
\text { mass }\end{array}$ & $\begin{array}{c}\text { Methane, } \\
\% \text { by } \\
\text { mass }\end{array}$ & $\begin{array}{c}\text { Ethene, } \\
\% \text { by } \\
\text { mass }\end{array}$ & $\begin{array}{c}\text { Ethane, } \\
\% \text { by } \\
\text { mass }\end{array}$ & $\begin{array}{c}\text { Propene, } \\
\% \text { by } \\
\text { mass }\end{array}$ & $\begin{array}{c}\text { Propane, \% } \\
\text { by mass }\end{array}$ & $\mid \begin{array}{c}\text { I-Butane, } \\
\% \text { by } \\
\text { mass }\end{array}$ & $\begin{array}{c}\mathrm{N}- \\
\text { Butane, } \\
\% \text { by } \\
\text { mass }\end{array}$ & $\begin{array}{c}\text { Sum of } \\
\text { butylenes, \% } \\
\text { by mass }\end{array}$ \\
\hline 1 & 0.440 & 14.75 & 18.53 & 2.06 & 12.45 & 3.34 & 13.26 & 5.40 & 9.95 & 0.71 \\
\hline 2 & 0.380 & 18.36 & 18.28 & 0.86 & 10.74 & 1.00 & 13.34 & 4.55 & 12.94 & 0.20 \\
\hline 3 & 0.444 & 14.33 & 24.41 & 0.54 & 10.50 & 0.73 & 14.45 & 4.87 & 13.39 & 0.35 \\
\hline 4 & 0.431 & 13.76 & 36.71 & 0.55 & 9.86 & 0.66 & 12.48 & 2.88 & 7.03 & 0.36 \\
\hline 5 & 0.481 & 11.04 & 44.18 & 0.50 & 8.08 & 0.36 & 10.56 & 3.15 & 8.44 & 0.00 \\
\hline 6 & 0.400 & 15.42 & 31.51 & 1.07 & 8.43 & 0.57 & 8.04 & 2.17 & 4.67 & 0.06 \\
\hline 7 & 0.445 & 15.99 & 3.64 & 0.03 & 7.26 & 0.04 & 16.54 & 6.13 & 18.46 & 0.00 \\
\hline 8 & 0.434 & 14.59 & 24.82 & 0.73 & 10.85 & 1.72 & 14.71 & 5.05 & 8.85 & 0.24 \\
\hline $\begin{array}{c}\text { Sample } \\
\text { No. }\end{array}$ & $\begin{array}{l}\text { I-Pentane, } \\
\% \text { by mass }\end{array}$ & $\begin{array}{c}\mathrm{N}- \\
\text { Pentane }, \\
\% \text { by } \\
\text { mass }\end{array}$ & $\begin{array}{c}\text { Hexane } \\
\text { and } \\
\text { higher, } \\
\% \text { by } \\
\text { mass }\end{array}$ & $\begin{array}{c}\text { Oxygen, } \\
\% \text { by } \\
\text { mass }\end{array}$ & $\begin{array}{c}\text { Nitrogen, } \\
\% \text { by } \\
\text { mass }\end{array}$ & $\begin{array}{l}\text { Carbon } \\
\text { oxide, \% } \\
\text { by mass }\end{array}$ & $\begin{array}{c}\text { Carbon } \\
\text { dioxide, \% } \\
\text { by mass }\end{array}$ & $\mid \begin{array}{c}\text { Hydroge } \\
\text { n sulfide, } \\
\% \text { by } \\
\text { mass }\end{array}$ & \multicolumn{2}{|c|}{$\underset{\mathrm{MJ} / \mathrm{m}^{3}}{\text { Calorific value }} Q_{\mathrm{n}}{ }^{\mathrm{r}}$, } \\
\hline 1 & 4.21 & 2.39 & 0.00 & 2.95 & 9.27 & 0.11 & 0.58 & 0.03 & & 20.91 \\
\hline 2 & 4.96 & 4.78 & 0.23 & 1.91 & 7.25 & 0.03 & 0.36 & 0.20 & & 22.83 \\
\hline 3 & 3.94 & 4.10 & 0.19 & 1.35 & 5.98 & 0.03 & 0.36 & 0.48 & & 21.27 \\
\hline 4 & 2.39 & 2.76 & 0.60 & 1.79 & 7.65 & 0.06 & 0.18 & 0.28 & & 23.98 \\
\hline 5 & 3.50 & 3.06 & 0.27 & 1.57 & 4.93 & 0.03 & 0.25 & 0.10 & & 22.96 \\
\hline 6 & 1.20 & 1.14 & 0.00 & 6.18 & 19.19 & 0.03 & 0.20 & 0.12 & & 25.45 \\
\hline 7 & 7.32 & 5.03 & 0.39 & 5.06 & 13.93 & 0.00 & 0.18 & 0.00 & & 18.80 \\
\hline 8 & 3.40 & 2.58 & 0.20 & 3.03 & 8.29 & 0.06 & 0.23 & 0.67 & & 21.88 \\
\hline
\end{tabular}




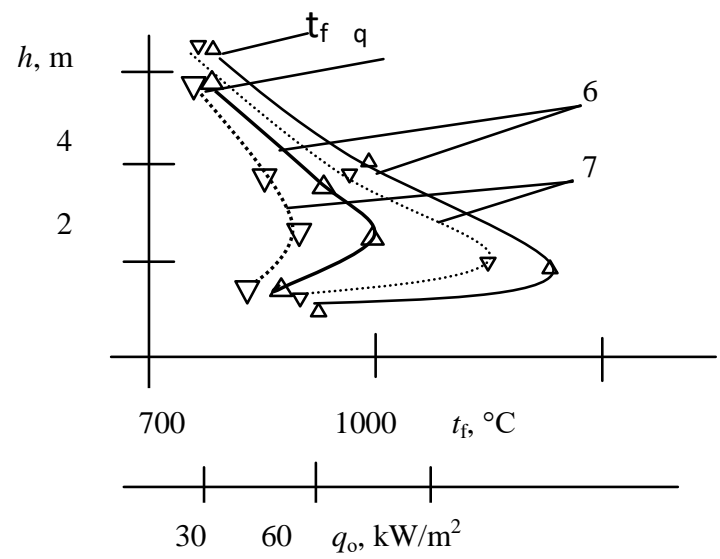

Fig. 3. Distribution of flame temperature $t_{\mathrm{f}}$ and heat flux from internal lining $q_{\mathrm{o}}$ along the height $h$ of ON-1000/1 and ON-1000/2 furnaces when burning methane-hydrogen fraction with the sample compositions No. 6 and 7 at an excess air coefficient of 1.3

The obtained experimental data of the nitrogen oxides NOx concentration and the burning rate $w$ of methane-hydrogen fraction in the $O N-1000 / 1$ furnace and natural gas in the TGM-84A boiler, depending on the calorific value $Q_{\mathrm{n}}{ }^{\mathrm{r}}$, are given in Table. 2 .

Table 2

The obtained experimental data of the burning rate $w$ of methane-hydrogen fraction in the ON-1000/1 furnace and natural gas in the TGM-84A boiler, depending on the calorific value $Q_{\mathrm{n}}{ }^{\mathrm{r}}$

\begin{tabular}{|c|c|c|c|c|c|c|c|c|}
\hline $\begin{array}{c}\text { Calorific } \\
\text { value } \\
Q_{\mathrm{n}}{ }^{2} \\
\mathrm{MJ} / \mathrm{m}^{3}\end{array}$ & $\begin{array}{c}\text { Density } \\
\rho, \mathrm{kg} / \mathrm{m}^{3}\end{array}$ & $\begin{array}{c}\mathrm{H}_{2} \\
\text { content, } \% \\
\text { by mass }\end{array}$ & $\begin{array}{c}\mathrm{CH}_{4} \text { content, } \\
\% \text { by mass }\end{array}$ & $\begin{array}{c}\text { Excess air } \\
\text { coefficient } \alpha\end{array}$ & $\begin{array}{c}\text { Fuel } \\
\text { consumpti } \\
\text { on, } \mathrm{m}^{3} / \mathrm{h}\end{array}$ & $\begin{array}{c}\text { Temperatu } \\
\text { re at the } \\
\text { outlet } \\
\text { from } \\
\text { burner } \\
T_{\mathrm{b}},{ }^{\circ} \mathrm{C}\end{array}$ & $\begin{array}{c}\mathrm{NO}_{\mathrm{x}} \\
\text { concentratio } \\
\mathrm{n}, \\
\mathrm{mg} / \mathrm{m}^{3} \text { (in } \\
\text { terms of } \\
\alpha=1.4)\end{array}$ & $\begin{array}{c}\text { Burning } \\
\text { rate } w, \\
\mathrm{~m} / \mathrm{s}\end{array}$ \\
\hline 25.43 & 0.540 & 10.1 & 28.3 & 1.3 & 1115 & 802 & 84.8 & 2.02 \\
\hline 26.68 & 0.536 & 10.05 & 28.27 & 1.1 & 1375 & 881 & 63.6 & 2.11 \\
\hline 22.83 & 0.38 & 18.36 & 18.28 & 1.1 & 1458 & 884 & 56.1 & 3.07 \\
\hline 33.94 & 0.69 & - & 98.89 & 1.1 & 32500 & 1150 & 136 & 0.84 \\
\hline
\end{tabular}

The distribution of heat fluxes from flame $q_{\mathrm{f}}$ over the burner height $h$ in the $T G M-84 A$ boiler during the combustion of natural gas is shown in Fig. 4. The calculated data for the combustion of the methane-hydrogen fraction with a hydrogen content of $10.05 \%$ and methane $28.27 \%$ is also presented in Fig.4. 


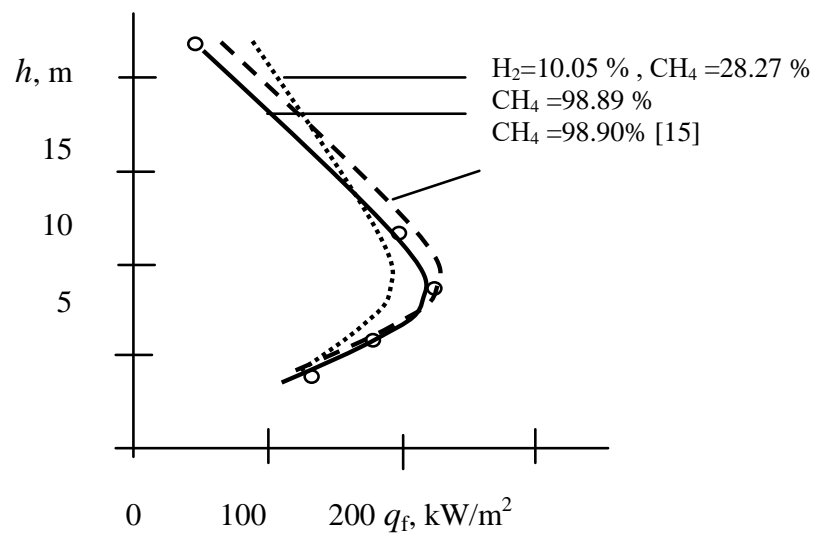

Fig. 4. Heat fluxes from flame $q_{\mathrm{f}}$ over the burner height $h$ in the TGM-84A boiler during the combustion of natural gas $\left(\mathrm{CH}_{4}=98.89 \%\right)$ in comparison with the calculated data for the combustion of the methane-

hydrogen fraction $\left(\mathrm{H}_{2}=10.05 \%, \mathrm{CH}_{4}=28.27 \%\right)$ for steam load of $255 \mathrm{t} / \mathrm{h}$ and with data [13] for the boiler PK-41

\section{Discussion}

As it is seen from table 1, the calorific value of the methane-hydrogen fraction is 55.5$75.1 \%$ of the calorific value of natural gas used as fuel for TPP boilers. The experimentally obtained distribution of the flame temperature and heat fluxes $q_{\mathrm{o}}$ incident from the inner lining over the height $h$ of the burners in the $O N-1000 / 1$ and $O N-1000 / 2$ furnaces when burning the methane-hydrogen fraction with the samples composition No. 6 and 7 at an excess air ratio of 1.3 is shown in fig. 3 .

As it can be seen from fig. 3, the conversion of $O N-1000 / 1$ and $O N-1000 / 2$ furnaces from the combustion of the methane-hydrogen fraction with combustion heat of $25.45 \mathrm{MJ} / \mathrm{m}^{3}$ (sample No.6) to the combustion of the composition with combustion heat of $18.8 \mathrm{MJ} / \mathrm{m}^{3}$ (sample No.7) leads to a temperature decrease in the flame core for $100{ }^{\circ} \mathrm{C}$ as an average. Heat fluxes $q_{\mathrm{o}}$ also significantly decrease; therefore, the operation of furnaces during the combustion of the methane-hydrogen fraction with low heat of combustion at the gas oil hydrotreatment unit is carried out only with a fresh catalyst that allows lower flame temperatures in a burner.

As it can be seen from table 2, an increase in the hydrogen $\mathrm{H}_{2}$ content from $10.05 \%$ to $18.36 \%$ (by mass) leads to an increase in the burning rate $w$ by $45 \%$. The burning rate of natural gas with methane content of $98.89 \%$ in the $T G M-84 A$ boiler is $0.84 \mathrm{~m} / \mathrm{s}$, i.e. 2.5 times lower than the burning rate of the methane-hydrogen fraction with $\mathrm{H}_{2}$ content of $10.05 \%$. Due to the low heat of combustion of the methane-hydrogen fraction, the concentration of nitrogen oxides $\mathrm{NO}_{\mathrm{x}}$ is on average 2 times lower compared to that during combustion of natural gas.

As it can be seen from fig. 4, the burning of the methane-hydrogen fraction $\left(\mathrm{H}_{2}=10.05 \%\right.$, $\mathrm{CH}_{4}=28.27 \%$ ) causes an increase in the incident heat fluxes $q_{\mathrm{f}}$ at the outlet of the furnace, which is accompanied by an increase in heat loads of the TGM-84A boiler superheater and leads to a decrease in efficiency, compared to that during operation of this boiler on natural gas. However, the distribution of heat fluxes of flame over height $h$ during combustion of the methane-hydrogen fraction is most suitable for a direct-flow boiler $P K-41$ [13] of supercritical pressure having a burner chamber pinch.

\section{Conclusions}

1. The burning of the methane-hydrogen fraction with a high, over $10 \%$ (by mass), hydrogen content instead of natural gas in the TPP power boilers is accompanied by increased values of the incident heat fluxes at the outlet of the burner. 
2. To reduce the amount of incident heat fluxes at the outlet from the boiler burner, it is necessary to increase the methane share in the methane-hydrogen fraction, which will reduce the rate of fuel combustion and ensure fuel combustion within the burner volume.

\section{References}

1. Tajmarov MA., Kuvshinov NE., Stepanova TO. Optimizaciya raboty pechej P-101 i P-101A na ustanovke L-24-600. Vestnik Kazanskogo tekhnologicheskogo universiteta.2015.18 (22):50-53 (In Russ).

2. Tanatarov MA., Ahmetshina MN., Faskhutdinov RA. Tekhnologicheskie raschety ustanovok pererabotki nefti. M: Himiya, 1987. (In Russ).

3. Sardanashvili AG., L'vova AI. Primery i zadachi po tekhnologii pererabotki nefti i gaza. M: Himiya, 1980. 256. (In Russ).

4Manovyan AK. Tekhnologiya pervichnoj pererabotki nefti i prirodnogo gaza .M: Himiya, 2001. 568. (In Russ).

5. Tajmarov MA., Dodov IR. Ustanovka dlya proizvodstva sinteticheskogo motornogo topliva.. Vestnik kazanskogo tekhnologicheskogo universiteta. $2015 ; 18(8): 162-166$.

6. Trembovlya VI., Finger ED., Avdeeva AA. Teplotekhnicheskie ispytaniya kotel'nyh ustanovok.2 nd ed. Moscow: Energiya 1977. (In Russ).

7. Tajmarov MA., Ahmetova RV., Lavirko YuV. Sungatullin RG., Zheltuhina ES. Snizhenie vrednyh vybrosov $\mathrm{v}$ atmosferu oksidov azota kotlami TES. Izvestiya KGASU 2017.39(1):180-188. (In Russ).

8. Zel'dovich YaB., Sadovnikov PYa., FrankKameneckij DA. Okislenie azota pri gorenii. M.-L: ANSSSR 1947 (In Russ).

9. Knorre GF., Aref'ev KM., Bloh AG., Nahapetyan EA., Paleev II., Shtejnberg VB. Teoriya topochnyh processov. M.-L.: Energiya 1966. (In Russ).

10. Bloh AG. Teploobmen v topkah parovyh kotlov. L.: Energoatomizdat 1984. (In Russ).

11. Aksyutin O., Ishkov A., Romanov K., et al. New Methane-Hydrogen Fuel Technology and its Potential Application in the Gas Industry. Development and Innovation in Focus All Eyes Turn to Perth for LNG 18. Report of the International Gas Union, April-September 2016, P. 74-76.

12. Kim JJ. Adsorption equilibria and kinetics of propane and propylene on zeolite $13 \mathrm{x}$ pellets. Microporous and mesoporous materials. 2019; 274: 286-298

13. Mirel I., Pentia D., Florescu C., et al.. Water treatment from swimming pool, piscine and swimming basins. Scientific Bulletin of Politechnica

\section{Литература}

1. Таймаров М.А., Кувшинов Н.Е., Степанова Т.О. Оптимизация работы печей П-101 и П-101А на установке Л-24-600 //Вестник Казанского технологического университета. 2015. №.22(18).C.50-53.

2. Танатаров М.А., Ахметшина М.Н., Фасхутдинов Р.А. Технологические расчеты установок переработки нефти. М: Химия,1987. $352 \mathrm{c}$.

3. Сарданашвили А.Г., ЛьвоваА.И. Примеры и задачи по технологии переработки нефти и газа. М: Химия, 1980. 256 с.

4. Мановян А.К. Технология первичной переработки нефти и природного газа .М: Химия, $2001.568 \mathrm{c}$.

5. Таймаров М.А., Додов И.Р. Установка для производства синтетического моторного топлива.// Вестник казанского технологического университета.2015. № 8(18). С.162-166.

6. Трембовля В.И., Фингер Е.Д., Авдеева А.А. Теплотехнические испытания котельных установок. 2-е изд., перераб. и доп. М.: Энергия, 1977, 297c.

7. Таймаров М.А., Ахметова Р.В., Лавирко Ю.В. Сунгатуллин Р.Г., Желтухина Е.С. Снижение вредных выбросов в атмосферу оксидов азота котлами ТЭС. // Известия КГАСУ. 2017. №1(39). C. $180-188$

8 Зельдович Я.Б., Садовников П.Я., ФранкКаменецкий Д.А. Окисление азота при горении. М.-Л.: Издательство АНСССР, 1947. 147 с.

9. Кнорре Г.Ф., Арефьев К.М., Блох А.Г., Нахапетян Е.А., Палеев И.И., Штейнберг В.Б. Теория топочных процессов. М.-Л.: Энергия, 1966. $492 \mathrm{c}$.

10.Блох А.Г. Теплообмен в топках паровых котлов. Л.: Энергоатомиздат, 1984. 240 с.

11. Аксютин О., Ишков А., Романов К., у ал. Новая технология метано-водородного топлива и eе потенциальное применение в газовой промышленности. Развитие и инновации в фокусе для СПГ 18. Доклад Международного газового союза, апрель-сентябрь 2016 г.С. 74-76.

12. Kim J.J. Adsorption equilibria and kinetics of propane and propylene on zeolite $13 \mathrm{x}$ pellets. Microporous and mesoporous materials. 2019. Vol. 
Проблемы энергетики, 2019, том 21, № 3

University of Timisoara. 2015; 60(2):79-83.

14. World Energy Outlook / International Energy Agency 2018:46.

15. Steadier Boom for the Oil Sands // Petroleum Economist. 2016. June. P. 8-10.

16. Short-term Canadian Natural Gas Deliverability 2015-2018. P. 6
274. P. 286-298.

13. Mirel I., Pentia D., Florescu C., Ionescu D. Water treatment from swimming pool, piscine and swimming basins/ Scientific Bulletin of Politechnica University of Timisoara. 2015. Vol. 60, № 2.pp 7983.

14. World Energy Outlook / International Energy Agency. 2018 pp 146.

15.Steadier Boom for the Oil Sands // Petroleum Economist. 2016. June. Pp. 8-10.

16.Short-term Canadian Natural Gas Deliverability 2015-2018. P. 63.

\section{Authors of the publication}

Mikhail A. Taymarov - Kazan State Power Engineering University.

Vladimir K. Ilyin - Kazan State Power Engineering University.

Evgeniy G. Chiklyaev- Kazan State Power Engineering University.

Rais G. Sungatullin- Kazan State Power Engineering University. 